\title{
Erişkin kavus ayağı
}

\section{Adult cavovarus foot}

\author{
Kaya H. Akan
}

S.B. İstanbul Medeniyet Üniversitesi, Göztepe Eğitim ve Araştırma Hastanesi, Ortopedi ve Travmatoloji Anabilim Dalı, İstanbul

Kas kuvvetlerinde dengesizlik sonucu oluşan cavovarus ayağı genellikle kalıtımsal duysal motor nöropatilere bağlı görülür. Diğer nedenleri arasında serebral palsi, serebral hasar (inme), ön boynuz hastalıkları (spinal kök yaralanması), talus boyun yaralanmaları ve çarpık ayak sekeli yer alır. Cavovarus ayak deformitesinde peroneus longus ve tibialis posterior kaslarının göreceli olarak kuvvetli olması ard ayağın varusa ve ayak önünün valgusa (pronasyona) gelmesine yol açar. Ayak arkasının varusta olması, ayağın lateral kısmına aşırı yüklenilmesine ve dolayısıyla ayak bileği instabilitesine, peroneal tendinite ve stres kırığına yol açar. Aşırı yük alan eklemlerde dejeneratif artritik değişiklikler ortaya çıkabilir. Yürüme muayenesi ile stance ve salınım fazı defisitlerini düzeltmek için gerekli tendon transferlerinin planlaması yapılabilir. Ayağın ön ve arka kısımlarının pozisyonlarının muayenesi, yumuşak doku gevşetmesi ile osteotomi gereksinimi olup olmadığını belirler. Coleman blok testi ayak arkasının varusunun saptanması için vazgeçilmez bir araçtır. Ortezlerin veya ayak desteklerinin uzun süre kullanılması kas dengesizliğine yol açarak deformitenin artmasına ve tendon ve eklemlerde dönüşümsüz hasar oluşmasına yol açabilir. Ayağın geriye dönüşümsüz hasarının engellenmesi için erken dönemde tendonların dengelenmesi esastır. Kas dengesizliği tendon transferleri, düzeltici osteotomiler ve artrodezlerle düzeltilebilir. Fikse kemik deformiteleri artrodez ve osteotomiler ile düzeltilebilir.

Anahtar sözcükler: ayak deformiteleri; cerrahi
The cavovarus foot deformity is often the end point of muscle imbalance and usualy caused by hereditary motor sensory neuropathies. The other causes of this deformity includes cerebral palsy, cerebral injury (stroke), anterior horncell disease, talar neck injury and clubfoot sequela and burns. The relative overpower of the peroneus longus and tibialis posterior muscles cause hindfoot varus and forefoot valgus (pronation). The varus of the hindfoot causes overloading on the lateral aspect of the foot, which may later result in ankle instability, peroneal tendinitis, and stress fracture. Degenerative changes can be seen in overloaded joints. Gait examination provides valuable information for planning tendon transfers to correct stance and swing-phase disorders. Inspection of the forefoot and hindfoot positions determines the need for soft tissue release and osteotomy. The Coleman block test is essential in differentiating the causes of the hindfoot varus. The inappropiate use of orthoses or supportive footwear can result in muscle imbalance which causes increases in the deformity and brings permanent damage to tendons and joints. Tendon rebalancing is a priority in order to prevent unsalvageable deterioration of the foot. Muscle imbalance can be corrected by tendon transfer, corrective osteotomy, and fusion. Fixed bony deformities should be handled by fusion and osteotomy.

Key words: foot deformities; surgery
P es cavovarus veya pes equinocavovarus, patomekaniği halen tam anlaşılmamış olan değişik etiyolojik nedenlere bağlı görülen karmaşık bir ayak deformitesidir. Deformitenin tanımında ayak mediyal arkının yüksek olması ve vücut ağırlığı ile arkın düzelmemesi yer alır (Mann). Deformitenin en sık rastlanan nedeni nöromusküler hastalıklar olsa da doğumsal pes equinovarus (PEV) sekeli olarak da görülebilir. Bu deformitelerin çok az bir kısmı idiyopatik olarak sınıflandırılır. Lovell ve arkadaşları ${ }^{[1]}$ ile Younger ve Hansen ${ }^{[2]}$ tarafından önerilen sınıflama sistemlerinde dört ana neden yer alır: nörolojik, konjenital, travmatik ve idiyopatik. Sınıflama etiyolojik olarak yapılır (Tablo 1).

\section{ETIYOLOJi}

\section{Nörolojik}

Eskiden idiyopatik nedenli olarak gösterilen olguların günümüzde \%80'ine yakın bir kısmının nörolojik kaynaklı olduğu görüşü öne sürülmüştür. ${ }^{[3]}$ Nörolojik

- İletişim adresi: Op. Dr. Kaya H. Akan, Sağlık Bakanlığı, İstanbul Medeniyet Üniversitesi, Göztepe Eğitim ve Araştırma Hastanesi, Ortopedi ve Travmatoloji Anabilim Dalı, İstanbul Tel: 0532 - 2529300 e-posta: drakan@sbgoztepe.gov.tr

- Geliș tarihi: 4 Eylül $2013 \quad$ Kabul tarihi: 5 Kasım 2013 
Tablo 1. Erişkin kavovarus ayağı nedenleri

\begin{tabular}{l}
\hline NÖROLOJiK \\
\hline Charcot-Marie-Tooth Hastalı̆̆ı \\
(Herediter motor duysal nöropati) \\
Friedrich Ataksisi \\
Spinal müsküler atrofi \\
Serebral palsi \\
Spinal kord lezyonları \\
(myelomeningosel, syringomyeli, spinal kord tümörleri vb.) \\
Serebral yaralanma \\
(inme) \\
Poliomiyelit \\
\hline TRAVMATiK \\
\hline Kompartman sendromu \\
Sinir yaralanması \\
Talus kırığı \\
Peroneal tendon yaralanması \\
Yanık \\
Ezilme yaralanması \\
lyatrojenik \\
(Aşil'in fazla uzatılması) \\
\hline DOĞUMSAL \\
\hline Çarpık ayak sekeli \\
Arthrogryposis \\
\hline iDiYOPATiK \\
\hline
\end{tabular}

kaynaklı olanların içerisinde en yüksek kalıtımsal motor ve duysal nöropatilerin (herediter motor ve sensöriyel nöropatiler - HMSN) kavus ayak deformitesine yol açan tipi motor ağırlıklı olanıdır. Kas dengesizliği agonist-antagonist kas gruplarında görülür. HMSN alt tiplerinde Tip I Charcot-Marie-Tooth (CMT) hastalığı miyelinopati, Tip II CMT hastalığı nöropati ve Tip III Dejerine-Sottas hastalığı (periferik demiyelinizasyon) yer almaktadır. Bu hastalıklar grubunun tanınmasında gen analizleri önemli rol oynamaktadır. Ancak genetik haritalandırma alt tiplerin oluşunu ve ayrıştırılmasını açıklasa da kesin bir tanı testi olmaması nedeniyle, tanı ayağın görünümü ve aile öyküsünün var olması ile konmaktadır. ${ }^{[2]}$ Periferik nöropati genellikle ayak intrensek kaslarında güçsüzlük yaparak daha proksimal tutuluma yol açar. Deformite mekanizmasında, uzun fleksör ve ekstansör tendonların ayak intrensek kaslarının gücünü aşmasına bağlı olarak interfalengeal (IF) eklemlerde fleksiyon ve metatarsofalengeal (MTF) eklemlerde hiperekstansiyona yol açması yatar. MTF eklemlerdeki subluksasyon giderek çıkığa dönüşür ve plantar yastığı metatars (MT) başının altından distale doğru iter. Bu nedenle daha proksimalde yer alan ince taban derisi de ayak basması sırasında yük alan MT başlarının altına gelir. Tibialis anterior ve peroneus brevis kaslarının zayıflığı birinci sıranın diğer MT başlarına göre daha fazla plantar fleksiyona gelmesine yol açar. Zaman içerisinde bu deformiteler fikse hale gelir. ${ }^{[2]}$ Eğer extensor hallusis longus (EHL) sağlamsa, hasta ayağı dorsifleksiyona getirmek için bu tendonu kullanacağından birinci parmak pençe deformitesi daha da belirgin hale gelir (Şekil 1).

Zayıf kalan tibialis anterior ve peroneus brevis kaslarına göre daha kurvetli olan tibialis posterior ve peroneus longus kasları, ayak arkasının varusa ve ayak önününde valgusa (pronasyona) gelmesine yol açar (Şekil 2). CMT hastalarında peroneus longus normal kas yapısına göre daha hipertrofiye olduğundan tibialis anterior ile bir dengesizlik yaratır. EHL, tibialis anterior çalışmadığı için daha da baskın hale gelip çıkrık mekanizması ile birinci MT başını daha da plantara bastırır. Bu aşamada ayak önü adduksiyonda ve birinci sıra plantar fleksiyondadır. Ayak bileğinde bu bozukluklara ek bir ekin gelişirse, hasta bu kez diz hiperekstansiyonda, adımını düşük ayak nedeniyle yüksekten atarak yürümeye başlar.

Kavovarus ayağın nörolojik ve doğumsal diğer nedenleri arasında proksimal tutulumun daha belirgin olduğu amiyotrofik lateral skleroz (Lou Gehrig Hastalığı), Huntington Koresi, Friedrich Ataksisi, beyin hasarı (inme gibi) gibi hastalıklar olup, bu hastalıklarda ayak, ekstremitenin proksimaline göre daha az önem taşımaktadır.

Serebral palsili hastalarda hasarlı motor korteks alanının miktarına göre gelişen spastisite ve güçsüzlük ile pes planovalgus veya pes cavovarus deformiteleri

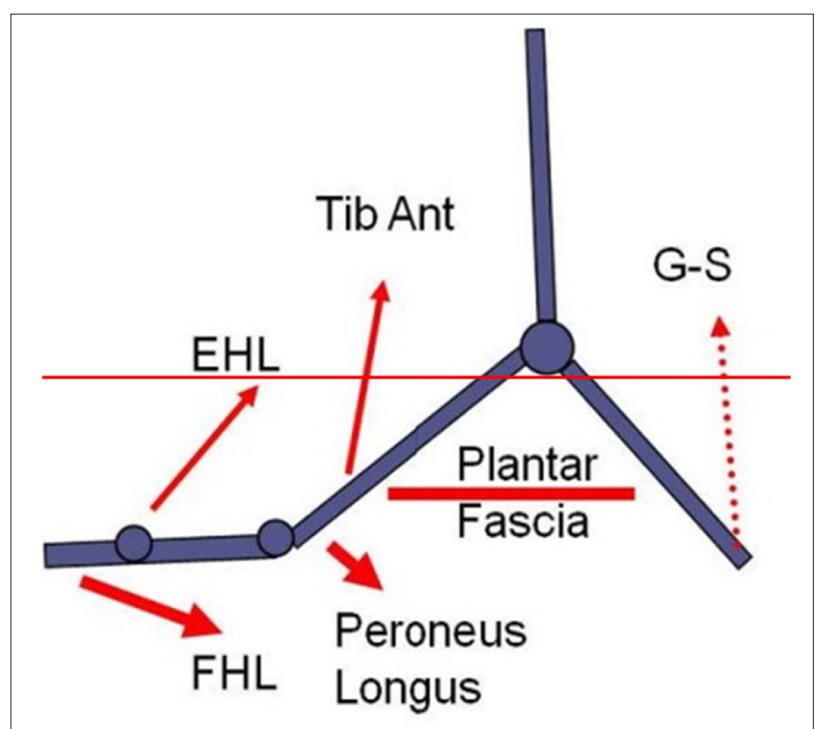

Şekil 1. Kavovarus ayakta kas patolojileri [Olney BW. Evaluation and Surgical Treatment of Cavus Foot deformities CME. American Academy of Orthopaedic Surgeons Web Site: Orthopaedic Knowledge Online 2009: 7(11)]. 


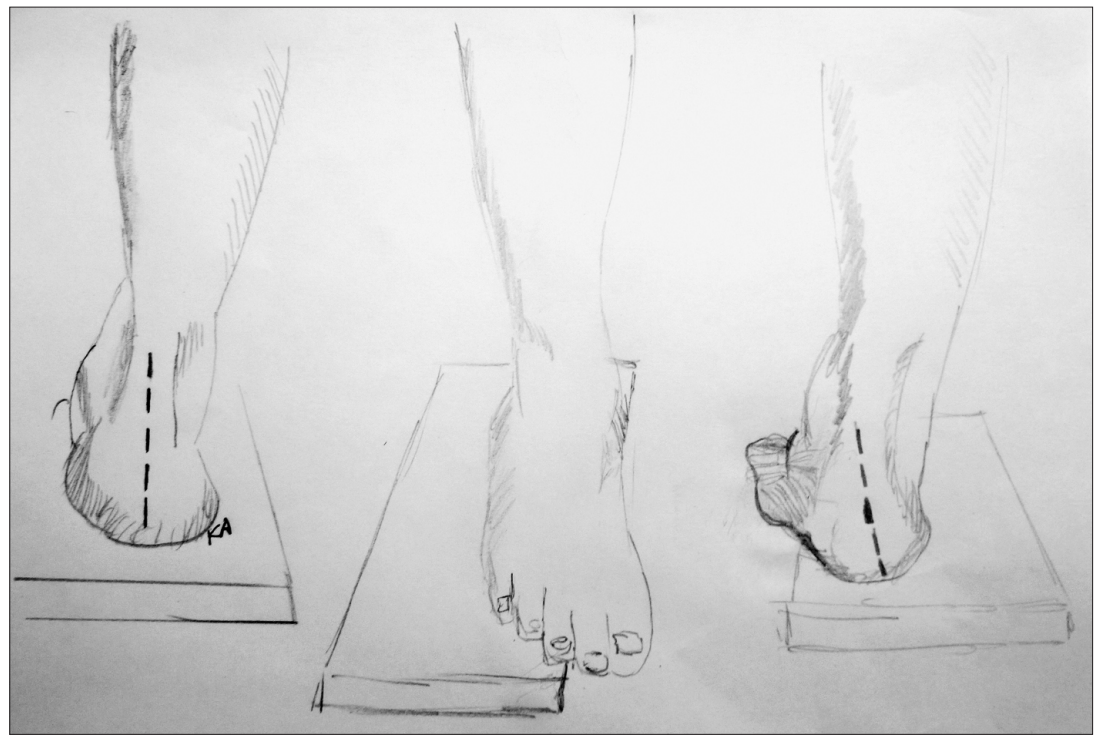

Şekil 2. Coleman blok testi.

oluşabilir. Serebral palside ayak tutulumu değişik tiplerde ve görünümlerde ortaya çıkmaktadır. Tek başına ekin deformitesi nadiren görülürken, varus veya valgusa deformitesi daima Aşil tendonunda gerginlik ile birliktedir. Deformite, yürüyüşün salınım ve basma fazlarında, özellikle esnek deformiteli hastalarda değişkenlik göstermektedir. ${ }^{[4]}$

Beyin kanaması veya kapalı kafa travması geçiren erişkin hastalarda ekin veya ekinovarus deformitesi gelişebilir. Tedavinin başarısı, tutulan santral alanın büyüklüğüne ve derecesine bağlıdır. Bilişsel fonksiyonları kötü olan veya inmeye bağlı motor, propriyoseptif veya duysal kaybı olan hastalar rekonstrüktif cerrahiden yarar görmezler. Tekerlekli sandalyede dolaşabilen bazı hastalarda ayakkabı giydirmek veya transferi kolaylaştırmak için tendon gevşetmeleri yapılabilir. Serebral yaralanma ile rekonstrüktif cerrahi arasında fonksiyonel iyileşme olabileceği için 18-24 ay beklenmesi tavsiye edilir. ${ }^{[4]}$

Poliomiyelit tarihsel olarak önemi olan ve medulla spinalis'te ön boynuz hücrelerini etkileyerek belirli spinal kökleri etkileyen aşağı motor nöron paralizisine yol açan bir hastalıktır. Kök tutulumunun seviyesi hastada kavovarus, planovalgus veya kalkaneus yürüyüşü gelişip gelişmeyeceğini belirler. Deformitenin boyutuna ve şekline bakarak poliomiyelitli hastaların sınırlı ayak füzyonlarından veya osteotomilerinden ve faz içi ve faz dışı kas transferlerinden yararlanabileceklerine karar verilebilir.

Amiyotrofik lateral skleroz ve spinal musküler atrofiler ilerleyici karakterde kavovarus ayak pozisyonuna yol açarlar. Tek taraflı ilerleyici bir kavovarus ayak intrensek bir spinal kord hasarı ile oluşabilir.
Diastamatomiyelide spinal kanalı torasik veya yüksek lomber seviyelerde sagittal planda ikiye bölen bir kemik spikülü veya fibröz bant vardır. Medulla spinalis ve aksiyel iskelet farklı hızlarda büyüdügüünden çocuğun gelişiminin ileri yıllarında belirsiz olarak kavus deformitesi ortaya çıkabilir. Kavus ayağın ilerlemesi tethered cord gevşetmesi için bir endikasyonu işaret eder. Skolyoza eşlik eden pes kavus varsa her iki durumun da nörolojik bir kökeni olduğu unutulmamalıdır.

\section{Travmatik}

Kompartman sendromları sonrasında özellikle posterior derin krural kompartman sendromunda oluşan tibialis posterior ve flexor digitorum longus kas kontraktürleri ayağın ekin ve kavovarus pozisyonuna çekilmesine yol açar. Yanıklarda, ezilme yaralanmalarından sonra veya venöz stazlarda ayağı kavovarus pozisyonuna çekebilir. Talusta oluşan bir boyun kırı̆̆ı, talus boynunu kısalmış bir şekilde dorsale ve mediyale transle ederek subtalar, talonaviküler ve kalkaneoküboid eklemlerde fikse varus pozisyonuna yol açabilir. ${ }^{[5]}$

Peroneal sinirin derin dalında veya L5 kökünde hasar oluşursa, peroneal güçsüzlüğe bağlı olarak tibialis posterior ve flexor hallucis longus kaslarının karşıt çekeni kalmaz ve ayak önü ve arkası varusa gelir. Örneğin, diz çıkığına bağlı kalıcı peroneal sinir hasarında ayak bileği veya ayakta ekinovarus pozisyonu oluşur ve tedavinin erken dönemlerinde çoklu tendon transferleri gerektirir. Topuk varusu peroneus brevis tendonunda tekrarlayan travmaya bağlı kalıc hasar ve yırtığa yol açabilir. Peroneus brevis tendonunun kaybı ağır bir kavovarus ayağa yol açabilir. ${ }^{[6]}$ 


\section{Konjenital nedenler}

Kavus ayak deformitesi konjenital PEV'in dört komponentinden birisidir (cavus, adduktus, ekinus, varus). PEV'in tamamlanmamış veya kötü gitmiş tedavilerinde veya hiç tedavi edilmemiş formlarında erişkinlerde kavovarus ve ekin pozisyonunun devam ettiği görülür. Ayak arkası ve önü birlikte varus poziyonundadır. Diğer sekel sorunlar arasında Aşil'in gereğinden fazla uzatılmasının yol açtığı kalkaneal yürüyüş veya talusun kubbesinin düzleşmesinin yol açtığı ayak bileği hareket kısıtlılığıdır. ${ }^{[7]}$

Konjenital multipl artrogripozis genellikle diğer bulguları nedeniyle tanınır ve sert fikse ekinovarus ayak deformitesine yol açar.

\section{4. İiyopatik}

Bazı hastalarda belirli bir neden bulunamayabilir. Bazı HMSN'lerin genetik paternleri halen bilinmediğinden, idiyopatik olarak kabul edilen birçok olgunun bu yolla açılanabileceği düşünülmektedir. İdiyopatik periferik nöropati, genellikle erken dönemde nöropatik ülserler, duysal bozukluklar ve motor tutulumu ile kendisini gösteren en kötü kavus ayak nedenidir. Hemen her olguda tendon transferleri ile kas dengesinin sağlanması, fizyoterapi ve ayakkabı modifikasyonları gerekir.

\section{PATOMEKANIK}

Normal ayakta kas fonksiyonları agonist-antagonist kas grupları arasındaki denge ile sağlanır. Patolojik olarak bu dengenin bozulması deformite oluşumuna yol açar. Kavovarus ayak birçok hastalığın sonlanma noktası olup ayak intrensek ve ekstrensik kaslarının dengesizliğine bağlı oluşur. ${ }^{[8]}$ Ayağın anormal pozisyonu önce esnek tipte deformiteyi yaratırken, dengesizlik arttıkça deformite rijid hale gelir.

Plantar fasya ayak intrensek kaslarının ve plantar nörovasküler yapılara göre yüzeysel yerleşimlidir. Kalkaneusun tüberine yapışarak transvers metatarsal bağa bantlar halinde gelir ve distalde fleksör tendon kıIıflarının her iki yanından parmaklara devam eder. ${ }^{[9,10]}$ Çıkrık (windlass) mekanizması ile parmak ucuna kalkma sürecinde, MTF eklemlerde pasif dorsifleksiyonda plantar fasya gerilir ve bu sayede mediyal arkı hem stabilize eder hem de yükseltir.

\section{KLINIK}

Klinikte kavovarus ayakta en sık instabilite ve ağrı semptomları görülür. Ayak bileği ve ayağın lateralinde varusa bağlı stres artışı vardır. Başlangıçta sık ayak burkulmaları ilk bulgu olarak ortaya çıkabilir. Ayak önünde ve arkasında varus olan PEV sekelli hastalarda lateralde küboid bölgesinde aşırı yüklenme olur. CMT hastalarında ayak dış kenarında, birinci MT başında veya lateral MT başlarında yüklenme olabilir. Baskının bu şekilde artışı en sık beşinci MT'de olmak üzere stres kırıklarına yol açabilir. Koşucularda ayağın kavus pozisyonu MT başlarında ve kalkaneusta yük artışına yol açabilir. ${ }^{[10]}$

Ayak arkasının varusa gelmesi lateral kollateral bağlarda, Aşil moment kolu da mediyale doğru yer değiştirdiğinden, sürekli yüklenme ve sürtünme yapar. Bu yüklenme lateral ayak instabilitesine yol açabilir. Aynı zamanda da pençe parmak deformitesine bağlı olarak distal metatarsal yağ yastıkçığı yer değiştirdiği için semptomatik metatarsalji görülebilir.

Kavus pozisyonunda uzun süre yürüme ayak bileğinde ve üçlü eklem kompleksinde (subtalar, talonaviküler, ve kalkaneoküboid eklemler) aşırı yüklenmeye yol açabilir. Ayak bileği mediyalinde dejeneratif değişiklikler görülürken, talusta varus tiltine ve buna eşlik eden lateral bağ gevşekliğine yol açabilir.

Benzer deformitenin ailede görülmesi kalıtımsal bir sorunu işaret eder. Tek taraflı kendiliğinden ayakta bir deformitenin ortaya çıkması, özellikle de nörolojik diğer bulgular eşlik ediyorsa spinal kord lezyonunu gösterir. Mutlaka ileri tetkik yapılması gereklidir.

\section{FiZiK MUAYENE}

Fizik muayene hastanın yürüyüşünün değerlendirilmesi ile başlar. Salınım fazında hastanın düşük ayağının olup olmadığı, parmakların hiperekstansiyonuna, ayağın önünün veya arkasının varus ya da valgus pozisyonunda olmasına dikkat edilmelidir. Hastalar hem yürüme hem de ayakta dururken muayene edilmeli ve alt ekstremite hizalanması ile ayağın duruş pozisyonuna bakılmalı, nasırların yerlerine bakarak yürüyüş tekrar değerlendirilmelidir. Tüm eklemlerin hareket açıkıkları ölçülmeli ve kaydedilmelidir. Ayak bileği dorsifleksiyon açıklığına diz hem fleksiyonda hem de ekstansiyonda iken bakılmalıdır. Her iki pozisyonda da ekin deformitesinin değişmemesi, ayağın dorsifleksiyonunu engelleyen mekanik bir sorunun olduğunu (anteriorosteofitler gibi eklem içi veya Aşil kısalığı, posterior kapsül gerginliği gibi eklem dışı sorun) gösterir. Diz düzken var olan bir ekin deformitesi dizin fleksiyonunda azalıyorsa, izole olarak gastroknemius kasının gergin olduğu anlaşıı.ır. Bazen ender olsa da izole soleus kası gerginliği benzer bir soruna yol açabilir.

Tüm kaslar ve sinirler hem güç hem de nörolojik yönden muayene edilmelidir. Her kasın gücü muayeneyi yapanın oluşturduğu aktif dirence karşı ölçülür ve 0-5 arasında bir derece ile kaydedilir. Tendon trajelerinde ağrı olup olmadığına bakılır. Tendon dengesizliği dinamik deformitelere yol açabilir. Dinamik deformite 
birinci MT'nin plantar fleksiyonunu daha da arttıracağından, kavus deformitesini de arttırabilir. Nörolojik muayenenin tam olabilmesi için reflekslere, duyuya ve vibrasyon yanıtlarına da bakılmalıdır.

Tibialis posterior kasına bağlı gelişen intrensek ayak arkası varusunu ayak önü varusundan ayırmak için Coleman blok testi yapılmalıdır (Şekil 2). Bu test ile ayak arkasının valgusa gelip gelmediği anlaşılabilir. Ayağın lateral kısmı tahta bir bloğun üzerine yerleştirilerek mediyal kolonun kenardan sarkmasına izin verilir. Eğer ayak arkası rijid değilse ve deformite de birinci sıranın plantar fleksiyonuna bağlı olarak artmışsa, kalkaneusa arkadan bakılınca valgusa doğru düzeldiği görülür. Bu da, ayak önü pozisyonu düzeltilirse, ayak arkası varusunun düzeleceğini gösterir. Ayak arkasının varusunun düzelmemesi fikse bir ayak arkası deformitesi olduğunu gösterir. Coleman blok testinin sonuçları fizik muayenenin geri kalanı ile değerlendirilmelidir, ancak genellikle ayak önü deformitesinin düzeltilmesinin yeterli olabileceğini gösterdiği kabul edilir. ${ }^{[7]}$

\section{RADYOLOJiK DEĞERLENDIRME}

Ayak ve ayak bileğinin basarak anteroposterior ve lateral grafileri ile kalkaneusun tanjansiyel grafisi mutlaka çektirilir. Basarak çekilen lateral grafilerde ölçülen açılar ile, kavovarus deformitesinin boyutu hakkında iyi bir fikir alınabilir (Şekil 3). Ayak oblik grafileri ile tarsometatarsal eklemlerde değişiklikler görüntülenebilir. Kavus ayağı olan hastalarda subtalar eklemin posteriorunda dejeneratif bir osteofit görülür. Coleman blok testi yapılırken çekilen bir ayak yan grafisinde birinci sıra osteotomisi ile elde edilecek düzeltme miktarı görülebilir. Modifiye Cobey grafisinde, ayak önünün hizalanması tanjansiyel kalkaneus grafisine göre daha iyi görülür. Talus boynunun kırık veya hizalanma bozukluğu için Canale grafisi en iyi yöntemdir. Bilgisayarlı tomografi (BT) taramaları ise ayak önü pozisyonu hakkında fikir verebilir, ancak yalnızca sanal bir basma görüntüsü sağlayabilirler. Ayak BT'si en iyi dejeneratif süreçler hakkında bilgi verebilir. Teknesyum 99 kemik taraması ise etkilenen eklemleri saptamada yol gösterici olabilir. Semptomatik hastalarda skopi kontrolünde semptomatik eklemlere anestezi uygulanarak ağrı kaynağı saptanabilir.

\section{KONSERVATIF TEDAVi}

Kavovarus ayakta birçok olgu yavaş seyirli ve stabil olduğundan, başlangıçta oldukça iyi konservatif tedavi edilebilirler. Tedavi protokolünde, deformitenin esnekliğine, tutulan ekstremitenin derecesine, temelde görülen nörolojik bozukluk düzeyine bağlı olarak değişik yöntemler uygulanır. Fizik tedavi ve rehabilitasyon, özellikle zayıf kas güçlendirilmesi, esnetmenin ilerletilmesi, ayakkabı veya ortez dizaynları oldukça işe yarar. Amaç eşit yük dağılımı olan plantigrad bir ayak sağlamaktadır.

\section{Ortezler}

Ayağın yük alan kısmını genişletmek ana amaçtır. Kişiye özel ortezlerin pahalı olmaları ve yüksek arklı

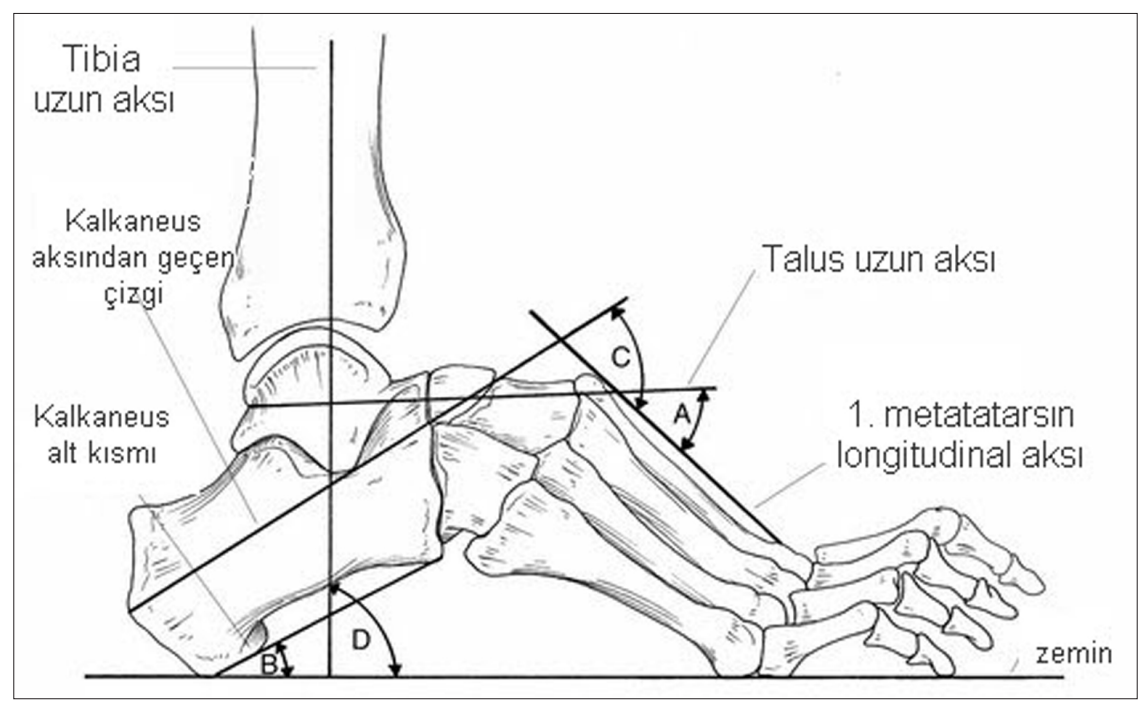

Şekil 3. Kavovarus ayakta, lateral basarak grafide radyolojik açılar. A: Meary açısı. B: Kalkaneal pitch açısı. C: Hibb açısı. D: Tibioplantar açı [Olney BW. Evaluation and Surgical Treatment of Cavus Foot deformities CME. American Academy of Orthopaedic Surgeons Web Site: Orthopaedic Knowledge Online 2009: 7(11)].. 
ayaklarda uyum güçlüğü olduğu için hastalar başlangıçta kendilerine uyarlanmış hazır tabanlık kullanmak isteyebilirler. Ayakkabı iç astarına MT yastığı yapıştırılabilir. Hastada birinci MT basısı varsa yastığın bu kısmı kesilip çıkarılabilir. Eğer modifiye tabanlık işe yararsa bunu kalıp olarak kullanıp bir üç katlı veya semirijid bir ortez imal edilebilir. Bu ortezin birinci MT başı kısmı kesilerek çıkarılıp metatarsal yastık yerleştirilebilir. Sert kavus ayağı olan hastalarda sert ortezler genellikle tolere edilemez. Yüksek arklı bir ortezin kullanılması, aslında ayak bileği instabilitesini arttırabilir ve modifiye edilmesi gerekir. Yüksek konçlu bir bot veya hazır bir ayak bileği breysi kullanılabilir. Velkrolu ayak bileklikleri ayakkabı veya bot içerisine daha rahat girer ve plastik yüksek ayak bilekliklerine yakın bir koruma sağlarlar. ${ }^{[2,7]}$

Kas güçsüzlüğü olan hastalarda düşük ayak varsa genellikle tam boy ayak-ayak bileği ortezlerinden (AFO) fayda görürler. AFO içerisine modifikasyon yapılması daha iyi kontrol sağlarken ekin deformitesinin ilerlemesini engellemek için breyse geçilebilir. Ekin kontraktürü ilerliyorsa her gece bir atel takılmalıdır. Breysleme özellikle Aşil uzatmalarından sonra mutlaka kullanılmalıdır. Genellikle deformite yalnızca posterior atel ve anterior bantlar ile engellenemeyeceği için bivalv bir alçı veya kapaklı bir breys kullanılarak müdahale edilmesi gerekir. ${ }^{[7]}$

\section{Ayakkabı giyimi}

Yüksek arklı ayak, ayakkabı içerisine özellikle bağcıksız ayakkabılara zor girer. Başlangıçta hazır alınmış, bağcıklı ve burun kısmı ekstra derin bir ayakkabı ile idare edilebilir. Bağcıklı bir botta ayağa biraz daha derin bir yuva sağlayarak ayak bileğini de biraz stabil eder. İnsert, tabanlık veya ortezlerin yerleştirilmesi için ve çok yüksek arklı ayaklarda veya ileri pençe parmak deformitelerinde ekstra derin ve özel yapım ayakkabıların kullanılması gerekebilir.

\section{CERRAHI TEDAVi}

Cerrahi planlama için hastanın yapılan detaylı muayenesi ve grafilerinin kontrolü sonrasında şu sorulara cevap aranmalıdır ${ }^{[11]}$ :

1- Deformite kavus mu, kavovarus mu, yoksa kalkaneovalgus mudur?

2- Kavus deformitesinin tepe noktası nerededir?

3- Ayak önü ekini fikse mi, yoksa esnek mi ve bütün MT'leri mi, yoksa yalnızca birinci sırayı mı içeriyor?

4- Eğer ayak arkası varusu varsa esnek mi (ayak önü deformitesine ikincil), yoksa fikse mi? (Coleman blok testi)
5- Ana deforme edici güçler kas dengesizliği ve yumuşak doku kontraktürleri mi (özellikle tibialis anterior, tibialis posterior kaslarına ve triceps surae kaslarına dikkat edin).

6- Daha iyi kas dengesi ve fonksiyon sağlayabilecek kas grupları hangileri?

7- Klinik olarak anlamlı parmak deformiteleri var mı? Flexor digitorum longus, ve extensor digitorum kasları çalışıyor mu?

8- Ayağın genel rijiditesi nasıl (elle düzeliyor mu?)?

9- Hastanın yaşı nedir?

10- Deformite etiyolojisi ilerleyici mi yoksa durağan mı?

Cerrahi bir seferde de yapılabilir ancak kademeli düzeltme için iki veya üç aşamalı düşünülmesi daha güvenle yaklaşılmasını sağlayacaktır. Planlamada sıralama yapılması her zaman yerinde olacaktır ${ }^{[12]}$ :

1- Kavus deformitesinin düzeltilmesi.

2- Ayak arkası deformitesinin düzeltilmesi.

3- Ayağın tendon transferleri ve/veya uzatmaları ile tekrar dengelenmesi.

4- Ayak parmak deformitelerinin düzeltilmesi.

Hastalarla cerrahi amaçlar, beklentiler ve düzelme zamanları açıkça konuşulmalıdır. Tüm normal eklemler mümkünse korunmalıdır. Kas güçsüzlüğü olan hastalarda iyi planlanmış olan osteotomiler ve tendon transferleri triple artrodezden daha güvenilir sonuçlara erişilmesini sağlar. Semptomatik eklemler dondurulmalı ve gergin yumuşak dokularda gevşetilmelidir. Gergin tendonlar gevşetilmeli veya transfer edilmelidir. Bu yapılamıyorsa kas-tendon bileşkesi fraksiyone olarak uzatılmalıdır. Osteotomiler, tendon transferleri veya gevşetmeleri nörojenik pes kavovarusu olan hastaların çoğununun kas dengesizliğini düzeltir. ${ }^{[2]}$

Tüm kavus ayaklar için tek bir cerrahi reçete yoktur. Amaç her deformiteyi adresleyen yaklaşımı bulmaktır. Bu kombine kemik ve yumuşak doku işlemi de olabilir.

\section{Yumuşak doku gevşetmesi ve tendon uzatılması}

Ekinovarus bir ayakta gerginlikler plantar ve mediyalde bulunan yapıları etkilediği için yerine göre posteromediyal gevşetme gerekebilir. Aşil tendon gerginliği tendon uzatması ile, izole gastroknemius gerginliği ise Vulpius ameliyatı ile düzeltilir. ${ }^{[13]} \mathrm{Bu}$ düzeltmeler yalnızca ayak basarak lateral grafilerinde görülebilen ayak arkası ekin deformitesi için uygulanır. Ayak önü ekini talus - birinci MT açısı ile ölçülür (normali 0-3º). Ayak arkası ekini kalkaneusun tepe (pitch) açısının ayak plantar fleksiyona giderken azalması ile ölçülür. ${ }^{[14]}$ Tek 
taraflı kavus ayağının normal taraf grafisi ile karşılaştırılması yararlı olur.

Yumuşak doku ameliyatları plantar fasya gevşetme$\mathrm{si}^{[15]}$ (Steindler prosedürü), gastroknemius geriletilmesi[16] (resesyonu), perkütan Aşil uzatması, ${ }^{[17]}$ modifiye Jones prosedürü[ ${ }^{[18]}$ ve tendon ameliyatları olarak sınıflanabilir.

Eğer sadece gastroknemius kompleksi gerginse, tek başına gastroknemius resesyonu yeterlidir (Strayer, Baumann ve Vulpius girişimleri). Diz hem fleksiyonda hem de ekstansiyonda iken ayak bileği pasif dorsifleksiyonuna bakılır. Eğer hareket açıklığı değişmiyor ve Aşil tendonu palpe edildiğinde gevşekse, ya posterior eklem kapsülü, ya anterior osteofit ya da gergin soleus kompleksi mekanik blok nedenidir. Basarak çekilen bir ayak bileği grafisinde anterior osteofitlere bağlı sıkışma görülebilir (Tablo 2).

Perkütan Aşil uzatması genellikle uzun süreli Aşil kontraktürleri için kullanılır ve amacı ayağı yaklaşık $10^{\circ}$ daha dorsifleksiyona getirmektir. ${ }^{[5]}$ Üç adet kesi ve her keside karşı taraftaki Aşil tendonunda gevşetme yapacak şekilde uygulanır.

Eğer Aşil açık yöntemle uzatılacaksa, kesi ayak bileğinin hemen posterior ve mediyalinden olmalıdır. Aşil tendonu bu keside derin diseksiyonla bulunur. Eğer geniş bir gevşetme planlanıyorsa nörovasküler yapılar bulunmalıdır. Aşil'in fazla uzatılması durumunda kalkaneus yürüyüşü ve plantar fleksiyonda zayıflık oluşabilir. Bu durum yürüyüşün durma fazında ayak arkası varusu ile birlikte ise split bir tibialis posterior tendon transferi yapılması gerekir. Flexor digitorum longus, ayak nötral pozisyondayken parmaklar fleksiyondaysa ya uzatılır ya da transfer edilir. Flexor hallucis longus tendonu Henry düğümünden gevşetilebilir, transfer edilebilir veya nerede güvenli bir şekilde ortaya çıkarılırsa orada fraksiyone olarak uzatılabilir. Flexor hallucis'in, çok güçsüz veya felçli bir peroneus brevis'e transferi çok etkin olabilir. ${ }^{[19]}$
İzole gastroknemius geriletmesi, mediyal bir insizyonla Aşil tendonu ile birleştiği yerden yapılır. ${ }^{[16]}$ Sural sinir, fasya ve tendon arasında doku katları oluşturulur. İzole gastroknemius tendonu kesilir ve yeterli olup olmadığına diz ekstansiyonda ayak bileği dorsifleksiyona getirilerek bakılır.

Birinci MT başının dinamik düşüklüğünün tedavisinde uygulanan modifiye Jones prosedüründe birinci parmak IF eklem füzyonu yapıldıktan sonra EHL tendonu yapışma yerinden kaldırılır. Birinci MT 1/3 distalinde horizontal seviyeden drille bir delik açıldıktan sonra $\mathrm{EHL}$ bu delikten geçirilir ve kendi üzerine, ayak bileği $10^{\circ}$ dorsifleksiyonda iken tutturulur. İşleme birinci MT dorsifleksiyon osteotomiside eklenebilir. ${ }^{[18]}$

Tendon transferi sonrasında yumuşak doku kontraktürleri ayak bileği ekleminin düzeltilmesini engelleyebilir. Bu durumda deltoid bağ mediyal malleolün posteriorundan gevşetilebilir. Ayak bileği ve subtalar eklem kapsüllerinin de gevşetilmesi gerekebilir. Nörovasküler demet izole edildikten sonra kapsül, tibialis posterior tendonunun anterior ve posteriorunda bulunur. PEV'de olduğu gibi sindesmozun posterior kısmını ayırıp talusun ayak mortisi içerisinde dönmesini sağlayabilir. Yüzeyel ve derin kompartmanları çevreleyen yağ ve fasyada skar dokusu ve gergin hale gelmiş olabilir ve gevşetilmesi gerekir.

Plantar fasyanın gevşetilmesi ile ayak kavusunda düzeltme sağlanabilir. ${ }^{[15]} \mathrm{Bu}$ işlem küçük birçok insizyon, eksizyon veya kalkaneustan geniş gevşetme tarzında yapılabilir. Ayak ortası kavus deformiteleri plantar fasya gevşetmesi ve gerekirse derin kompartman aksları ve tendonlarının kılıflarının gevşetilmesi ile yapılmalıdır. Talonaviküler eklem kapsülüne ekstensil bir gevşetme de yapılabilir. Eğer yumuşak doku gevşetmesi ayağın pozisyonunu düzeltemiyorsa, ayağı nötrale getirmek için osteotomiler veya füzyon gerekecektir. ${ }^{[20]}$

Travma ve kompartman sendromundan sonra düzeltme, tendon gevşetmeleri, kasla birlikte infarksiyon

Tablo 2. Yumuşak doku gevşetmesi ve tendon uzatma işlemleri

\begin{tabular}{lll}
\hline $\begin{array}{l}\text { Diz fleksiyonda ayak bileği } \\
\text { zorlamalı dorsifleksiyon derecesi }\end{array}$ & $\begin{array}{l}\text { Diz ekstansiyonda ayak bileği zorlamalı } \\
\text { dorsifleksiyon derecesi }\end{array}$ & Cerrahi işlem \\
\hline$>10$ & $<5$ & Gastroknemius resesyonu \\
$0-10$ & 5 (dorsifleksiyon) ile 20 (plantar fleksiyon & $\begin{array}{l}\text { Gastroknemius resesyonu ve/veya açık aşil } \\
\text { uzatması }\end{array}$ \\
$<0$ & 20 (plantar fleksiyon) & Açık veya perkütan aşil uzatması \\
$<0$ & Diz fleksiyonu ile değişmiyor (aşil gergin değil & Açık eklem debridmanı ve posterior gevşetme \\
$<0$ & Diz fleksiyonu ile değişmiyor (aşil gergin) & perkütan Aşil uzatması ve eğer ayak \\
düzelmezse posterior gevşetme
\end{tabular}


alanının uzaklaştırılması, ve kas-tendon üniteleri ile birlikte tendon transferleri ve düzeltici osteotomiler ile birlikte sağlanacaktır. Volkmann iskemik kontraktüründe kalıcı gevşetme için oldukça fazla miktarda nekrotik ve skar haline gelmiş tendon dokusunun çıkarılması gerekebilir. Bu tür bir cerrahiyi gerçekleştirebilmek için ekstremitenin nörovasküler anatomisinin çok iyi bilinmesi gerekir. ${ }^{[21,22]}$

\section{Tendon transferleri}

Alt ekstremite tendon transferlerinde ayak ve ayak bileğini kontrol eden kas-tendon üniteleri yürüyüşün ya basma, ya da salınım fazına göre ayrılırlar (Tablo 3). İstenen, transfer edilen tendonun asıl çalıştığı yürüyüş fazına uygun transferidir. Bu sayede ameliyat sonrası daha az rehabilitasyon ihtiyacı olacak ve güç kaybı minimalize edilecektir. ${ }^{[23]}$ Faz dışı transferler (örneğin tibialis posterior'un tibialis anterior tendonuna transferi) alt motor nöron hasarı olan genç hastalar için tavsiye edilir (Tablo 4). Flexor digitorum longus ve flexor hallucis longus tendonlarının anteriora transferi, inme hastalarında faz dışı transfer olarak kullanılmıştır. Tendon transferinde bilinmesi gereken bazı kurallar vardır:
1- Transfer edilecek kasın yerine alındığı kasın işini yapabilecek gücü ve ekskürsiyonu (taşması) olmalıdır. Transfer sonrası bir derece güç kaybı görülecektir.

2- Transfer edilecek tendon, yerine geçtiği tendona yakın tutulmalı ve mümkünse düz bir hat üzerinden gelmelidir.

3- Transfer edilecek tendon, ya kendisine ait tendon kılıfı veya yerine geçtiği tendonun kılıfı içinde olmalı, ya da kaymasına izin verecek dokuların içine alınmalıdır.

4- Transfer edilecek tendonun nörovasküler yapılarına zarar gelmemesi gerekir.

5- Tendonun çalıştıracağı eklemin sağlam olması gerekir (hareket açıklığının yeterli olması, stabil olması ve minimal deformitesinin olması).

6- Tendon ya direkt olarak kemiğe tutturulmalı ya da indirekt olarak bir başka tendona zigzag yaparak gerginliğini de hafif ile orta arasında tutarak yapılmalıdır. Örneğin tibialis posterior tendonu intraosseöz membran içerisinde transfer edilerek mediyal

Tablo 3. Yürümenin salınım ve basma fazlarında faz içi tendon transferleri

\begin{tabular}{|c|c|c|c|c|}
\hline Faz & Verici & Alıcı & Endikasyon & Birlikte yapılan işlem \\
\hline \multirow[t]{5}{*}{ Salınım } & Extensor hallucis longus & Tibialis anterior & $\begin{array}{l}\text { Birinci sıra pençeleşmesi } \\
\text { ve dorsifleksiyon zayıflığı }\end{array}$ & $\begin{array}{l}\text { Birinci sıra IF füzyon + } \\
\text { MTF eklem gevşetmesi }\end{array}$ \\
\hline & Extensor hallucis longus & Peroneus tertius & $\begin{array}{l}\text { Salınım fazında } \\
\text { inversiyonla birlikte } \\
\text { dorsifleksiyon zayıflığı }\end{array}$ & $\begin{array}{l}\text { Birinci sıra IF füzyon + } \\
\text { MTF eklem gevşetmesi }\end{array}$ \\
\hline & Extensor digitorum brevis & $\begin{array}{l}\text { Extensor digitorum longus } \\
\text { güdüğü }\end{array}$ & Pençe parmaklar & $\begin{array}{l}\text { IF füzyon veya eksizyon, } \\
\text { MTF eklem gevşetmesi }\end{array}$ \\
\hline & Extensor digitorum longus & Peroneus tertius & $\begin{array}{l}\text { Pençe küçük parmaklar; } \\
\text { zayıf dorsifleksiyon }\end{array}$ & $\begin{array}{l}\text { IF füzyon veya eksizyon, } \\
\text { MTF eklem gevşetmesi }\end{array}$ \\
\hline & $\begin{array}{l}\text { Tibialis anterior (komplet } \\
\text { veya split) }\end{array}$ & Peroneus tertius & $\begin{array}{l}\text { Salınım fazında aşırı } \\
\text { ayak önü inversiyonu }\end{array}$ & \\
\hline \multirow[t]{6}{*}{ Basma } & Flexor hallucis longus & Peroneus brevis & $\begin{array}{l}\text { Zayıf ayak bileği } \\
\text { eversiyonu }\end{array}$ & Kalkaneal osteotomi \\
\hline & Flexor hallucis longus & Peroneus longus & Esnek ayak önü varusu & Ayak ortası füzyonu \\
\hline & Peroneus longus & Peroneus brevis & $\begin{array}{l}\text { Zayıf ayak bileği } \\
\text { eversiyonu }\end{array}$ & Kalkaneal osteotomi \\
\hline & Peroneus brevis & Peroneus longus & $\begin{array}{l}\text { Zayıf ayak bileği } \\
\text { eversiyonu ve esnek ayak } \\
\text { önü varusu }\end{array}$ & Kalkaneal osteotomi \\
\hline & $\begin{array}{l}\text { Tibialis posterior (komplet } \\
\text { veya split) }\end{array}$ & Peroneus brevis & $\begin{array}{l}\text { Zayıf ayak bileği } \\
\text { eversiyonu }\end{array}$ & Kalkaneal osteotomi \\
\hline & $\begin{array}{l}\text { Tibialis posterior (komplet } \\
\text { veya split) }\end{array}$ & Peroneus longus & $\begin{array}{l}\text { Ayak önü varusu ve zayıf } \\
\text { ayak bileği eversiyonu }\end{array}$ & Kalkaneal osteotomi \\
\hline
\end{tabular}

$\mathrm{IF}=$ İnterfalengeal, MTF= Metatarsofalengeal

Younger AS, Hansen ST Jr. Adult cavovarus foot. J Am Acad Orthop Surg 2005;13(5):302-15.'ten adapte edilmiştir. 
kuneiformun içerisine tibialis anterior'a zigzag ile tutturularak yerleştirilebilir. Agonistler antagonistlere tercih edilir. Tibialis posterior tendon transferlerinde, verici sahaya zarar verilip verilmediği hâlâ tartışma konusudur. Kavus ayak pozisyonunda gevşetilen tendon, daha sonra kemik ve bağlar mediyal arkı desteklediği için, ileride bir planovalgusa yol açmaz. Bunun aksine tibialis posterior tendonu esnek tipte planovalgus ayakta mediyal kolonun önemli bir parçasıdır ve gevşetmesi dikkatle planlanmalıdır.

İnme hastalarında Aşil tendon uzatması tek başına yetmeyebilir. Ayak bir kez düzeltildiğinde tibialis posterior topuğu varusa getireceğinden aynı anda bir tibialis posterior tendon uzatması veya transferi de yapılmalıdır. Aşil tendonunu gereğinden fazla uzatmak kavus deformitesini arttıracağı veya kalkaneus yürüyüşü oluşturacağı için bundan kaçınılmalıdır. Fazla uzatılmış bir Aşil tendonu aynı zamanda plantar fleksiyonda zayıflamaya, parmak kalkışında yürüyüşün bozulmasına ve bazı olgularda ayak bileğinde anterior sıkışmaya yol açabilir. Bunlara ek olarak kuadriseps kasının vücudun öne doğru devrilmesini engellemek için toparlanması için daha fazla enerji harcanması gerekebilir. Gergin olan parmakların uzun fleksörlerinin gevşetilmemesi, sonucu daha da kötüleştirip ikincil ameliyatlara yol açabilir. ${ }^{[24]}$ Tendon gevşetmelerinin veya transferlerinin uygun bir şekilde yapılması, ayağın nötrale getirilmesini ve breys kullanımının iyileştirilmesini veya tamamen bırakılmasını sağlayabilir. Yürüme kapasitesi cerrahi sırasında hastanın yaşına ve paralizinin derecesine bağlıdır. Hemiplejisi olan hastalarda flexor digitorum longus'un ve flexor hallucis longus'un öne transferi dorsifleksiyon kuvvetini arttırabilir.

\section{Osteotomiler}

Osteotomiler hafif veya orta düzeyde kavovarus ile ileri düzey ve fikse kavus ayaklarda endikedir.
Osteotomiler yumuşak doku ve tendon işlemlerine ek olarak basit düzeyde tutulabileceği gibi, ayak ortası ostetomileri gibi çok daha agresif işlemlere de gereksinim olabilir.

Kalkaneus lateralizasyon osteotomisi, basma fazında Aşil tendonunun topuk üzerinde uyguladığı varus moment kolunu efektif bir şekilde düzeltebilir; bu osteotomi aynı zamanda parmak kalkma fazında Aşil tendonunun tibialis posterior'a uyguladığı ek deformasyonu peroneus brevis lehine bozabilir. Distal tibiası internal rotasyonda olan hastalarda da, Aşil tendonu ayak bileğinde bir varus momenti yaratır. Tibial rotasyonun derecesi BT ile saptanabilir. ${ }^{[2]}$

Uygun tendon gevşetmelerinden sonra hafif ve orta derecede fikse deformitesi devam eden ve komşu eklemlerinde artritik değişiklikleri olmayan hastalara osteotomi endikasyonu konur. Osteotomi, aynı zamanda füzyon yapılırken ayak pozisyonu düzeltilemiyorsa, kombine işlem olarak da düşünülür. Örneğin bir ayak bileği füzyonu sonrasında ayak arkası tamamen düzelmiş, ancak birinci sıra plantar fleksiyonu nedeniyle ayak önü düzelmemiş olabilir. Bu durumda birinci MTF ekleme veya proksimal metafizer bölgeye bir osteotomi yapma zorunluluğu doğar.

Ayak önü, arkası ve ayak bileğinde varusu olan bir hastada distal tibial osteotomi işe yarayabilir. Supramalleolar bölgeye yapılacak bir lateral kapalı kama ostetomisi, ayağın yere düz basmasını sağlayacak ve gücü ayak bileğinin içerisine yansıtacaktır.

Supramalleolar bölgede rotasyon osteotomileri de faydalı olabilir. Distal tibianın rotasyonu Aşil tendonunun moment kolunu değiştirecektir. Distal tibianın eksternal rotasyon osteotomisi subtalar ekleme gelen valgus momentini arttırarak subtalar eklemi açacaktır. Kavovarus ayaklı birçok olguda talonaviküler eklem serbestleştirildikten sonra ayak tibia üzerinde doğru hizalanır.

Tablo 4. Salınım fazı yetmezliklerinde faz dışı tendon transferleri

\begin{tabular}{|c|c|c|c|}
\hline Verici & Alıcı & Endikasyon & Birlikte yapılan işlem \\
\hline Tibialis posterior & $\begin{array}{l}\text { Tibialis anterior ve/veya } \\
\text { peroneus tertius }\end{array}$ & $\begin{array}{l}\text { Alt motor nöron patolojisi veya } \\
\text { sinir/kas hasarına bağlı zayıf } \\
\text { dorsifleksiyon }\end{array}$ & Aşil tendon uzatması \\
\hline Peroneus longus & Peroneus tertius & Zayıf dorsifleksiyon & $\begin{array}{l}\text { Tibialis posterior transferi; Aşil } \\
\text { uzatması }\end{array}$ \\
\hline $\begin{array}{l}\text { Flexor hallucis longus ve } \\
\text { digitorum longus }\end{array}$ & 4. MT- interosseöz membran & İnmeye bağ|ı zayıf dorsifleksiyon & $\begin{array}{l}\text { Kısa fleksör gevşetme; aşil } \\
\text { tendonu veya tibialis posterior } \\
\text { uzatması }\end{array}$ \\
\hline Flexor digitorum longus & Extensor hood & Parmakların intrensek deformitesi & IF eklem füzyonu veya eksizyonu \\
\hline
\end{tabular}

Younger AS, Hansen ST Jr. Adult cavovarus foot. J Am Acad Orthop Surg 2005;13(5):302-15.'ten adapte edilmiştir. 


\section{Kalkaneal osteotomi}

Ayak arkası pasif olarak nötrale getirilemiyorsa, kalkaneusa lateralizasyon osteotomisi subtalar füzyon eklense de eklenmese de yapılmalıdır. Ayak arkası varusunun değerlendirilmesi güç olduğundan herhangi bir şüphe varsa gene osteotomi eklenmelidir. Kalkaneus osteotomisi topuk vuruşu sırasında ve istirahatte ayak duruşunu düzeltecek ve daha önemlisi parmak kalkışı sırasında Aşil tendonunun moment kolunu lateralize edecektir. Mobil bir ayak ortası ve arkası olan bir hastada, lateralizasyon ayağın parmak kalkışı fazında mediyal kenarına gelen yükü arttırır. CMT hastalarında sık rastlanan şekilde, eğer birinci sıra plantar fleksiyonda ise mutlaka dorsifleksiyon osteotomisi eklenmelidir. ${ }^{[2,7,25]}$

Kalkaneus lateralizasyon ostetomisi gerektiren birçok hastada subtalar eklemin mediyalinde ve posteriorunda osteofit bulunur. Dejenerasyon bulgusu olarak yalnızca bu varsa ve semptomlar hafifse, osteofit mediyalden girilip flexor digitorum longus'un hemen önünden eksize edilebilir.

Dwyer kapalı kama osteotomisi, Aşil tendonunun moment kolunu yalnızca zayıflatır ve tam düzeltme sağlayamaz. Eksizyon yapılmaksızın yalnızca kaydırma osteotomisi genellikle tercih edilir. ${ }^{[7,25]} \mathrm{Bu}$ işlemde posterior lateral bir insizyon yapılır. Kalkaneus kesisi ayağın uzun aksına transvers olarak yapılır ve bu sayede uzatma veya kısaltmaya neden olmaz. Mediyaldeki kesi sustentaculum tali'den nörovasküler yapılara yakın olması nedeniyle uzak olmalıdır. Nörovasküler demet ile kalkaneal tüberin arasına bir cilt işareti konabilir. Cerrahın baskın olmayan elinin bir parmağı işaretin üzerinde dururken testere bu işarete yönlendirilir. Tüber fragmanı mobilize edildikten ve Aşil tendonunu çevreleyen derin fasya mobilize edildikten sonra laterale translasyon gerçekleştirilir. Osteotomi iki vida ile yerine tutturulur. Tüber fragmanının lateral kenarı tıraşlanır ve istenen herhangi bir yerde kemik grefti olarak kullanılır. [26,27]
Posterior kalkaneal osteotomi, zayıf gastroknemiussoleus kompleksine bağlı ayak arkası kavusunun düzeltilmesi için plantar fasya gevşetmesiyle birlikte kullanılır. Kalkaneusun tüberinin posteriora ve superiora oblik bir ostetomi ile kaydırılmasını takiben kalkaneusun pozisyonu düzeltilir ve triceps surae kasının zayıf kaldıraç kolu düzeltilir (Şekil 4). ${ }^{[28]}$ Anterior ayak bileği sıkışması olan bir hastada posterior kalkaneal ostetomi yapılırsa sıkışma artacaktır. Bu nedenle anterior sıkışma olup olmadığına dikkat etmek gerekir.

$\mathrm{Bu}$ işlemde kalkaneus kırığında kullanılan $\mathrm{L}$ veya $\mathrm{J}$ şeklinde kesinin bir kısmı kullanılır. Bu insizyon, subtalar füzyon sonrası varus düzeltmesi yetersiz ise bir sinus tarsi insizyonu ile kombine edilebilir. Ostetotomi Aşil tendon yapışma yerinin ve plantar fasyanın önünden başlar ve transvers yapılır. Plantar fasyanın gerisinde kalan bir osteotomide stabilizasyon bozulur. Oblik bir ostetomi tuber kalkanei'yi uzatır veya kısaltır ve kalkaneusun uzatılması da yumuşak doku örtüsünü fazlasıyla gereceği için varus düzeltmesini engelleyebilir. Mediyal duvarın anteriorundan çıkan oblik bir ostetomi nörovasküler demeti yaralayabilir.

Osteotomi alanı eğri bir küret veya bir periost elevatörü ile kaldırılır. Aşil tendon kılıfı tüber fragmanının displasmanını kolaylaştırmak için gevşetilir. Fasya gevşetilmezse Aşil tendonunun translasyonunu engelleyecektir. Tüber fragmanı iki vida ile tutturulur. Distal vidayı yerleştirdikten sonra osteotominin posterior fragmanının üst kısmını mediyale döndürerek ikinci vida ile tespit edilir. Radyolojik tetkikler (ayak bileği lateral ve Broden grafileri) yapılarak vidaların subtalar ekleme girmediğinden emin olmak gerekir. ${ }^{[29]}$

\section{Lateral kolon kısaltması}

Lateral kolon kısaltması ayak arkası varusunu, ayak önü varusunu ve adduksiyonunu düzelttiği için PEV sekeli bir ayak için idealdir. Lateral kolon kısaltması

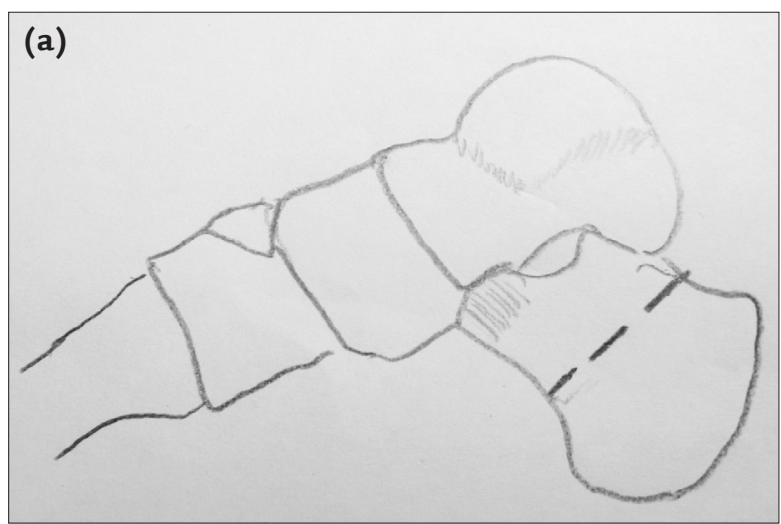

(b)

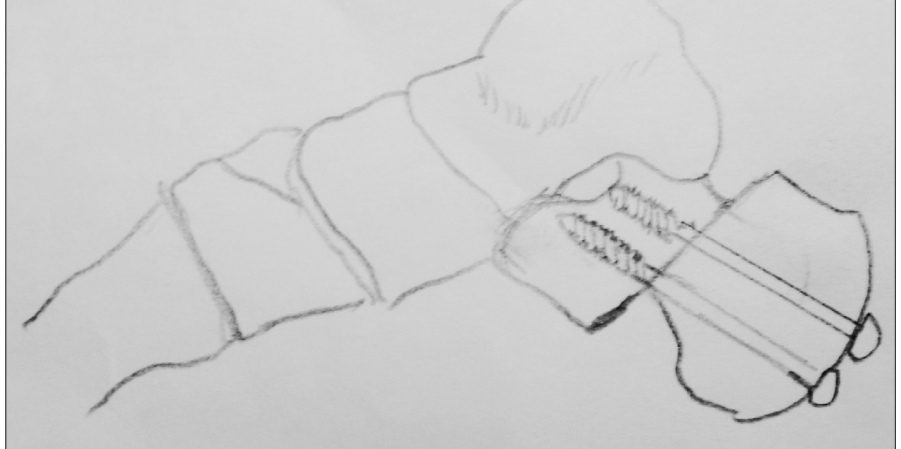

Şekil 4. Posterior kalkaneal osteotomi. 
küboidden, kalkaneusun lateral kenarından veya kalkaneoküboid eklemden yapılabilir. Eğer mediyal talonaviküler gevşetme sonuç vermezse bu işlem endikedir.

\section{Talus boyun osteotomisi}

İyi redükte edilmemiş bir talus boyun kırı̆̆ı talus boynunun distal kısmının hem dorsal hem de mediyale translasyonuna ve kısalmasına yol açar. Bu da ayağın kavovarus poziyona gelmesine neden olur. Yanlış kaynama üçlü eklem kompleksini kilitleyerek ayak lateraline fazla yük binmesine ve ağrılı rijid bir ayağa yol açar. Hatalı kaynama bölgesinde olduğu kadar subtalar ve midtarsal eklemlerde rotasyon ve translasyon oluşur. Bunun sonucu subtalar, talonaviküler ve kalkaneoküboid eklemlerde yüklenme ortaya çıkar. ${ }^{[2]}$

Talus boyun osteotomisi komşu eklemlerde artritik değişiklikler yoksa yapılabilir. Gereken düzeltme miktarını saptamak için cerrahi öncesi BT, kanlanma hakkında bilgi almak için ise manyetik rezonans (MR) gerekir. Bu işlemin riskleri arasında defomitenin tüm komponentlerindeki düzeltmenin kaybedilmesi, distraksiyon greftinin kaynamaması ve talus gövdesinin osteonekrozu olabilir, ancak sonuçları yüz güldürücü olarak bildirilmektedir. ${ }^{[30]}$

\section{Birinci sıra dorsifleksiyon osteotomisi}

Birinci sıranın dorsifleksiyon osteotomisi, birinci sıranın semptomatik plantar fleksiyonu ve buna bağlı olarak birinci MT başı altında yüklenmeye bağlı ayak önü ağrısı olduğunda ${ }^{[31]}$ ve aynı zamanda da ayak önünün yol açtığı ayak arkası varusunun yarattığı supinasyona bağlı ayak dış kenarında yüklenmeyle birlikte ağrı ve birinci sıranın semptomatik plantar fleksiyonu varsa endikedir. Buna MTF eklemin dorsalde kontraktürü, birinci sıra pençeleşmesi ve ekstansör tendon gerginliği de eşlik eder. Bu osteotomi veya birinci tarsometatarsal eklem
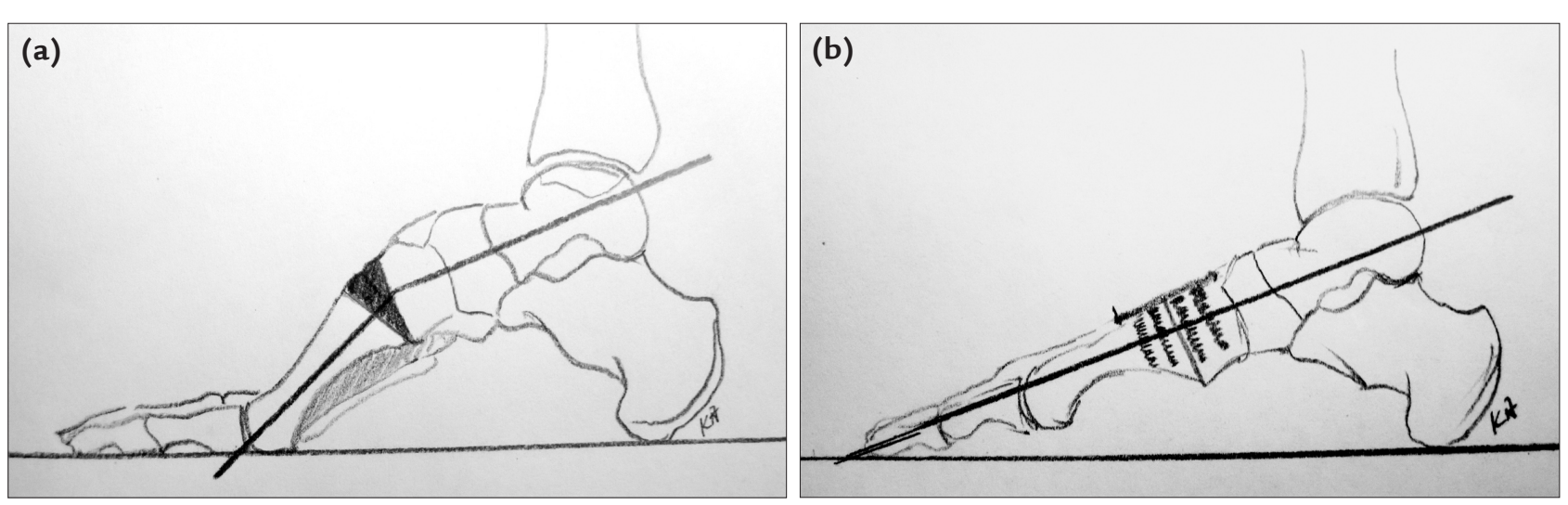

füzyonu, Coleman blok testiyle ayak arkası varusuna ayak önünün yol açtığı gösterilirse de endike olur. ${ }^{[2]}$

Birinci tarsometatarsal eklemin artrodezi, eklemin hipermobilitesinde ve peroneus longus'un birinci sırayı plantar fleksiyona kuvvetle çektiği hastalarda uygulanır. Birinci sırayı çok kısaltmamaya veya aşırı yukarı almamaya dikkat etmek gerekir. Birinci sırayı yükseltmek için eş zamanlı plantar fasya gevşetmesi gerekebilir. ${ }^{[32]}$

Tarsometatarsal artrodezde, eklemdeki birinci kesi hemen her zaman ekleme paralel, talus ve naviküler kemikten geçen hayali bir çizgiye dik gelecek şekilde yapılır. Distal kesi birinci MT aksına dik gelecek şekilde yapılır. Çok az miktarda çıkarılan kemik (5-8 mm) bile büyük düzelme sağlayabilir. Aksiyel hizalanmanın dikkatle yapılması, ameliyat sonrası dönemde talus ve birinci MT'nin hizalanmasının düzgün olmasını sağlayacaktır. İdeali, plantar bağları gergi bandı oluşturacak şekilde sağlam bırakmaktır (Şekil 5a). Basit bir şekilde, ayak bileği nötral dorsifleksiyonda ayak birinci ve beşinci MT başları altında baş parmağınızı tutarak hizalanma ve düzeltme miktarı kontrol edilebilir (Kitaoka). Eş zamanlı olarak, Jones transferi ve MTF eklemi gevşetecek bir dorsal kapsülotomi yapılabilir. Kama kapatılarak, 1/4 tübüler plak ve kortikal vidalar ile fikse edilir (Şekil 5b). Bu sayede talus birinci MT hizalanması sağlanmış olur.

MT boylarının aynı ve MT başlarının aynı seviyede olmalarına dikkat etmek gerekir. İkinci MT başı birincinin distalini 4-5 mm geçmişse ikinci MT kısaltma osteotomisi yapmak gerekir.

Alternatif bir teknikte, proksimal MT metafizinden kemik çıkarılır (5 mm'lik dorsal bir kama MT başını yaklaşık $12 \mathrm{~mm}$ kaldıracaktır) (Şekil 6a). Ayak hizalanması bir önceki şekilde sağlanır. Birinci tarsometatarsal eklemin hizalanması göstermek için ince bir Kirschner teli kullanılması, kesinin düzgün yapılmasını

Şekil 5. Tarsometatarsal eklem artrodezi.

Şeki 5. Tarsometatarsal eklem artrodezi. 


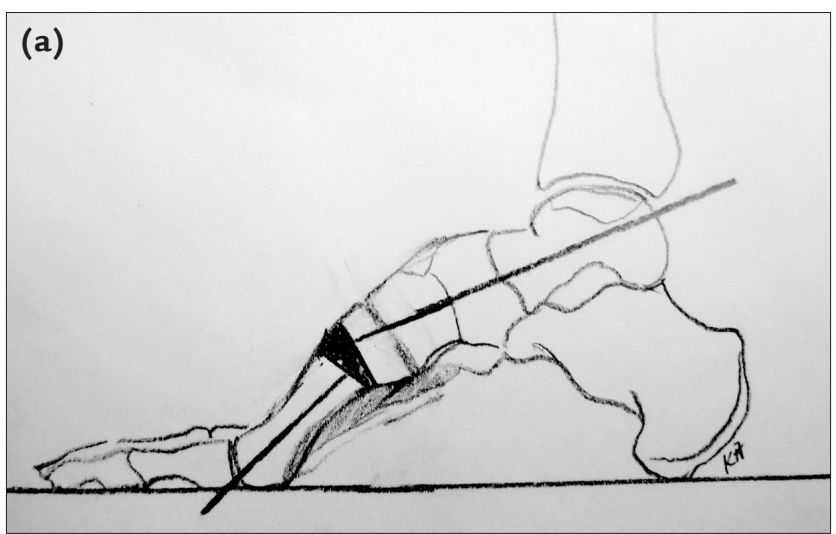

Şekil 6. Birinci MT dorsifleksiyon osteotomisi.

sağlayacaktır. Tespit iki veya üç delikli bir $1 / 3$ tübüler plak ve 3,5 mm'lik kortikal vidalarla yapılır (Şekil 6b). Bu osteotomi de birincisi gibi talusu birinci MT ile aynı hizaya getirecektir. ${ }^{[2]}$

\section{Ayak ortası osteotomileri}

Ayak ortası (global) kavus deformitesinin osteotomiler ile düzeltilmesi ya çoklu tarsometatarsal seviye osteotomilerinde (Jahss osteotomisi) ${ }^{[33]}$ ya da naviküler ve kuneiform eklem seviyesinde (Cole ve Japas ostetomileri) ${ }^{[34,35]}$ kemik segmentinin çıkarılması ve kapalı kama osteotomisi ile füzyonla yapılır. En sık görülen komplikasyonu osteotomi alanının açık kalması ve hatalı kaynamadır. MT gövde ostetomileri de deformiteyi düzeltebilir ve alçı içerisinde redükte pozisyonda tutulabilir. Osteotomi sahasında düzeltmeyi sağlamak için plantar fasya gevşetmesi yapmak gerekebilir. Jahss osteotomisinden sonra tüm MT başları aynı seviyede olmalıdır. Aksi halde plantar fleksiyonda bir sıra metatarsaljisine yol açabilir.

\section{Füzyonlar}

Kavovarus bir ayakta ikincil dejeneratif değişiklikler oluştuktan sonra artrodez endikasyonu vardır. Ancak bu işlem kas dengesizliğini kompanse etmek için kullanılmamalıdır. Örneğin tibialis posterior kasının çekmesi düzeltilmeden yapılan bir triple artrodezde, ayak bileği laterale açılabileceği ve bu da deformitenin tekrarlamasına yol açabileceği için, başarısız kalabilir. Bu nedenle ayağa doğru pozisyonun verilmesi için kas dengelenmesi artrodezle eş zamanlı yapılmalıdır.

Ayak arkası varusu subtalar dejenerasyona yol açmışsa subtalar füzyon yapılabilir. Ayağı talus üzerinde dışa döndürerek fiksasyondan önce sinus tarsi'nin kapatılması ile ayak arkası varusu düzeltilerek yapılabilir. Kalkaneoküboid eklem füzyona dejeneratif değişiklikler varsa veya lateral kolon kısaltması yapılacaksa eklenir.

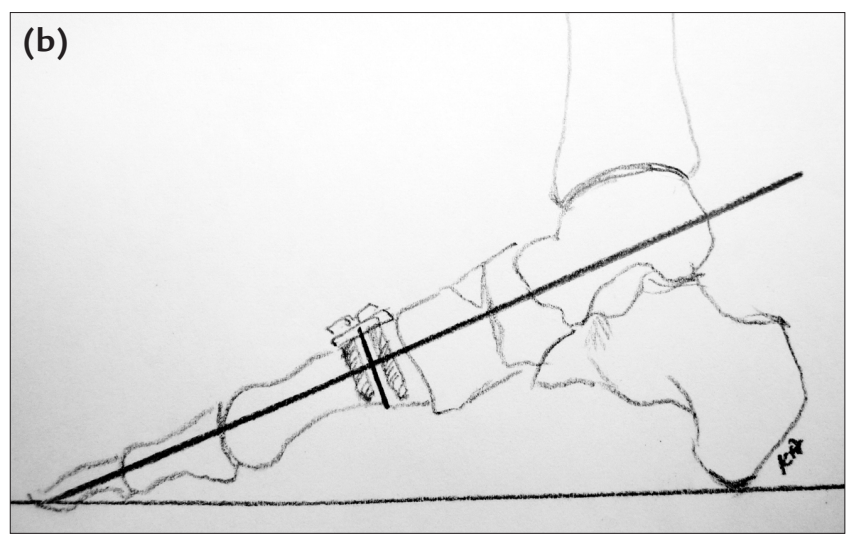

Eğer subtalar füzyonla deformite düzeltilemiyorsa veya talonaviküler ve/veya kalkaneoküboid eklem artrozik ise triple artrodez endikasyonu konur. İzole talonaviküler füzyon diğer eklemlerin hareketliliğini çok azalttığı için tek başına nadiren endikedir. Ayak bileği ve talonaviküler eklemde artrozu olan veya hem ayak bileği hem de subtalar eklemde sekonder dejeneratif değişiklikleri olan hastalarda, çoklu ayak arkası füzyonu tek seçenek olarak kalabilir.

Füzyonlar, talusun beslenmesine dikkat edildiği sürece tek seferde yapılabilir. Sıralamada önce ayak bileği deformitenin çoğu düzeltilerek dondurulur. Subtalar, talonaviküler ve kalkaneoküboid eklemler (üçlü eklem kompleksi) redükte edilir ve geri kalan deformitenin düzeltilmesi için dondurulur. Ek olarak kalkaneal osteotomi de gerekebilir.

Eğer deformitenin ayak önüne bağlı bir komponenti varsa veya ileri kavus varsa, Siffert gaga üçlü artrodezi zor bir teknik olmasına karşın güçlü bir düzeltme sağlar. ${ }^{[36]}$

Talusun beslenmesini bozmamak için triple ve ayak bileği füzyonunu ayrı seanslarda yapmak daha iyi olabilir. Ayak bileği eklemi subtalar veya ayak bileği artrodezinden sonra daha az semptomatik olabilir. Her füzyon yönteminde avantaj ve dezavantajlar vardır ve klinik duruma göre karar verilmelidir.

\section{Pençe parmakların düzeltilmesi}

Kavovarus ayağı olanlarda genellikle pençe parmak deformitesi vardır. Deformite esnek, kontrakte ve sublükse rijit, veya MTF eklem seviyesinden çıkık olabilir. Dinamik pençe parmaklar, ayak arkası deformitesi düzeltilince düzelir. Esnek deformiteli dinamik pençe parmaklarda Girdlestone veya Taylor prosedürleri ile fleksörün ekstansöre transferi uygundur. Fikse deformitelerde ya kapalı osteoklazi ya da IF eklem füzyonu 
veya eksizyonu gerekir. Eş zamanlı olarak bir Jones prosedürü veya ayak lateral kenarına ekstansör tendon transferi gerekir.

\section{SONUÇ}

Kavovarus ayak klinik olarak ayak mediyal longitudinal arkının yüksekliğinin ayak önünün varusu ile birlikte olması şeklinde tanımlanan, birçok farklı etiyoloji ile oluşabilen ve ayakta kas dengesizlikleri ile karakterize bir bozukluktur. Nörolojik bir bozukluğun ilk bulgusu olabileceği için dikkatle tetkik edilmelidir.

Tedavisi, ayak deformitesinin yerine ve boyutuna bağlı olarak düzenlenir. Ana amaç plantigrad, ağrısız bir ayak sağlamaktır. Hastalığın esnek ve hafif tiplerinin ilk tedavisi konservatif olup fizik tedavi, esnetme, ortez ve atelleri içerir. Deformitenin ilerleme eğiliminin olması veya konservatif tedavinin başarısız kalması cerrahi tedavileri gerektirebilir. Cerrahide amaç kas dengesini düzenlemek için yumuşak doku işlemleri, ileri deformitelerde kemik düzeltme ameliyatlarının eklenmesi ve artroz gelişmiş ise dondurma işlemlerine geçmek olmalıdır. Cerrahi planlama dikkatle ve her bir hasta için ayrı şekillendirilmelidir.

\section{KAYNAKLAR}

1. Morrissy RT, Winter RB, editors. Lovell and Winter's Pediatric Orthopaedics. Philadelphia, PA: Lippincott Williams \& Wilkins, 2006.

2. Younger AS, Hansen ST Jr. Adult cavovarus foot. J Am Acad Orthop Surg 2005;13(5):302-15.

3. Ward CM, Dolan LA, Bennett DL, Morcuende JA, Cooper RR. Long-term results of reconstruction for treatment of a flexible cavovarus foot in Charcot-Marie-Tooth disease. J Bone Joint Surg Am 2008;90(12):2631-42. CrossRef

4. Johnson AH, May CJ. Adult Cavovarus Foot. Orthopaedic Knowledge Online Journal 2012. http://orthoportal.org/ oko/article.aspx?article=OKO_FOO042\#abstract

5. Sangeorzan BJ, Wagner UA, Harrington RM, Tencer AF. Contact characteristics of the subtalar joint: the effect of talar neck misalignment. J Orthop Res 1992;10(4):544-51.

6. Tenuta J, Shelton YA, Miller F. Long-term follow-up of triple arthrodesis in patients with cerebral palsy. J Pediatr Orthop 1993;13(6):713-6.

7. Shurnas, PS, Coughlin MJ. Arthritis, Postural Disorders, and Tendon Disorders. In: Coughlin MJ, Mann RA, Saltzman CL, editors. Surgery of the Foot and Ankle. 8th ed. Philadelphia: Mosby Elsevier; 2007. p.803-922.

8. Samilson RL, Dillin W. Cavus, cavovarus, and calcaneocavus: An update. Clin Orthop Relat Res 1983;(177):125-32.

9. Sarrafian SK, Topouzian LK. Anatomy and physiology of the extensor apparatus of the toes. J Bone Joint Surg Am 1969;51(4):669-79.

10. Sneyers CJ, Lysens R, Feys H, Andries R. Influence of malalignment of feet on the plantar pressure pattern in running. Foot Ankle Int 1995;16(10):624-32.
11. Herring JA. Disorders of the foot. In: Tachdjian's Pediatric Orthopaedics. 4th ed. Philadelphia: Saunders; 2007. p.1139-66.

12. Olney BW. Evaluation and Surgical Treatment of Cavus Foot deformities CME. American Academy of Orthopaedic Surgeons Web Site: Orthopaedic Knowledge Online 2009: 7(11).

13. Pinney SJ, Hansen ST, Sangeorzan BJ. The effect on ankle dorsiflexion of gastrocnemius recession. Foot Ankle Int 2002;23(1):26-9.

14. Yalçınkaya ŞS, Özerdemoğlu RA, Mumcu EF. Pes kavus deformitesinin radyolojik özelliklerinin değerlendirilmesi. Acta Orthop Traumatol Turc 2001;35:292-8.

15. Steindler A. The treatment of pescavus (hollow claw foot). Arch Surg 1921;2:325-37.

16. Strayer LM Jr. Recession of the gastrocnemius: an operation to relieve spastic contracture of the calf muscles. J Bone Joint Surg Am 1950;32-A(3):671-6.

17. Dehne R. Congenital and acquired neurologic disorders. In: Coughlin MJ, Mann RA, Saltzman CL, editors. Surgery of the Foot and Ankle, 8th ed. Philadelphia: Mosby Elsevier; 2007. p.1761-806.

18. de Palma L, Colonna E, Travasi M. The modified Jones procedure for pes cavovarus with claw hallux. J Foot Ankle Surg 1997;36(4):279-83.

19. Saraph V, Zwick EB, Uitz C, Linhart W, Steinwender G. The Baumann procedure for fixed contracture of the gastrosoleus in cerebral palsy. Evaluation of function of the ankle after multilevel surgery. J Bone Joint Surg Br 2000;82(4):535-40.

20. Sherman FC, Westin GW. Plantar release in the correction of deformities of the foot in childhood. J Bone Joint Surg Am 1981;63(9):1382-9.

21. Santi MD, Botte MJ. Volkmann's ischemic contracture of the foot and ankle. evaluation and treatment of established deformity. Foot Ankle Int 1995;16(6):368-77.

22. David A, Lewandrowski KU, Josten C, Ekkernkamp A, Clasbrummel B, Muhr G. Surgical correction of talipes equinovarus following foot and leg compartment syndrome. Foot Ankle Int 1996;17(6):334-9.

23. Jeng $C$, Myerson M. The uses of tendon transfers to correct paralytic deformity of the foot and ankle. Foot Ankle Clin 2004;9(2):319-37.

24. Renzenbrink GJ, Buurke JH, Nene AV, Geurts AC, Kwakkel G, Rietman JS. Improving walking capacity by surgical correction of equinovarus foot deformity in adult patients with stroke or traumatic brain injury: a systematic review. J Rehabil Med 2012;44(8):614-23. CrossRef

25. Krause FG, Sutter D, Waehnert D, Windolf $M$, Schwieger $\mathrm{K}$, Weber M. Ankle joint pressure changes in a pescavovarus model after lateralizing calcaneal osteotomies. Foot Ankle Int 2010;31(9):741-6. CrossRef

26. Dwyer FC. Osteotomy of the calcaneum for pescavus. J Bone Joint Surg Br 1959;41-B(1):80-6.

27. Hansen ST Jr. Functional Reconstruction of the Foot and Ankle. Philadelphia, PA: Lippincott Williams \&Wilkins; 2000.

28. Mitchell GP. Posterior displacement osteotomy of the calcaneus. J Bone Joint Surg Br 1977;59(2):233-5.

29. Sabir M, Lyttle D. Pathogenesis of pescavus in Charcot-MarieTooth disease. Clin Orthop Relat Res 1983;(175):173-8.

30. Suter $T$, Barg A, Knupp M, Henninger $H$, Hintermann $B$. Surgical technique: talar neck osteotomy to lengthen the medial column after a malunited talar neck fracture. Clin Orthop Relat Res 2013;471(4):1356-64. CrossRef 
31. Watanabe RS. Metatarsal osteotomy for the cavus foot. Clin Orthop Relat Res 1990;(252):217-30.

32. Breusch SJ, Wenz W, Döderlein L. Function after correction of a clawed great toe by a modified Robert Jones transfer. J Bone Joint Surg Br 2000;82(2):250-4.

33. Jahss $\mathrm{MH}$. Tarsometatarsal truncated-wedge arthrodesis for pescavus and equinovarus deformity for the fore part of the foot. J Bone Joint Surg Am 1980;62(5):713-22.
34. Cole WH. The classic: the treatment of claw-foot. By Wallace H Cole. 1940. Clin Orthop Relat Res 1983;(181):3-6.

35. Japas LM. Surgical treatment of pescavus by tarsal V-osteotomy. Preliminary report. J Bone Joint Surg Am 1968;50(5):927-44.

36. Siffert RS, del Torto U. "Beak" triple arthrodesis for severe cavus deformity. Clin Orthop Relat Res 1983;(181):64-7. 